\title{
KNOWLEDGE MANAGEMENT BASED ORGANIZATIONS
}

Gjorgji Manev, Institute for Sociological, Political and Legal Research, Skopje, Macedonia

Jorde Jakimovski", Institute for Sociological, Political and Legal Research, Skopje, Macedonia

\begin{abstract}
Accomplishment of the goals set by a business organization implies implementation of knowledge management. It allows coordination of the working processes with the information technologies, with a view to adapting the organization's operations to the problems encountered. Overcoming these problems involves designing and implementation of complex business systems supported by information technology. This can be achieved by management that will monitor the business processes through clear indicators, with the purpose of accomplishing the preset strategic goals. This managerial staff must be fully devoted and committed to their work, to learning and creation of expertise that will help overcome the competition challenges.
\end{abstract}

Key words: business management, knowledge management, information technologies, computer business networks

JEL classification: D83, M10, M15

\section{ORGANIZACIJE BAZIRANE NA UPRAVLJANJU ZNANJEM}

Sažetak: Ostvarivanje ciljeva postavljenih od strane poslovne organizacije podrazumeva primenu upravljanja znanjem. Ona omogućava koordinaciju radnog procesa sa informacionim tehnologijama, a u cilju prilagođavanja poslovanja organizacije problemima na koje se nailazi. Prevazilaženje ovih problema podrazumeva projektovanje $i$ implementaciju kompleksnih poslovnih sistema, podržanih od strane informacionih tehnologija. Ovo se može postići upravljanjem koje će pratiti poslovne procese kroz jasne pokazatelje, u cilju ostvarivanja prethodno postavljenih strateških ciljeva. Takav menadžerski kadar mora da bude u potpunosti posvećen i privržen svom

\footnotetext{
*jakjor@isppi.ukim.edu.mk
} 
poslu, učenju $i$ stvaranju stručnosti koji će pomoći u prevazilaženju izazova konkurencije.

Ključne reči: poslovni menadžment, menadžment znanja, informacione tehnologije, računarske mreže u poslovanju

\section{INTRODUCTION}

The problems encountered by all businesses are related to stirring up the organization. They arise as a result of the constant attempts made by competition to outdo the others with their products/services marketed. Therefore, priority number one is proper identification of the organization problems. They are most commonly related to the employees, the applied equipment and technologies, awareness of the organization's capacities and achievements, as well as strong familiarity with the business environment.

Business environment encompasses: the domestic market, the regional markets and those in the neighboring countries, as well as the international markets (Porter, 1988). Consequently, incomes can be realized from domestic sources and from export, which should be accompanied by increase in productivity. That, in turn, can improve the living standard of the management, the employees and the owners of the business company. Therefore, it is of crucial importance to know well your competition, and in case a problem arises, it has to be well identified, defined and studied. Only after that can it be settled in a creative manner.

For the above mentioned reasons, management and business necessitate a successful and an integrated business system that can meet the organizationrelated requirements. Such systems applying the organization's knowledge, stored in the employees themselves or in the business processes, are supported by various configurations of computer networks, computer and telecommunication equipment and technologies, information systems, document management systems used for support of knowledge storage, and diverse software applications. Basically, we are talking about the basis of an organization's information structure, which can later be used to implement, for instance, the organization's databases.

The impact of application of information technologies in organizations can be identified in: the working method, the intra-organizational and interorganizational integration, changes in the competition's capacities, the organization structure and changes in the way of the management's operation (Morton, 1992).

This way ensures integration of the organization system, which has to be supported by knowledge about the organization and the business, the 
organization's staff, as well as everything needed for successful usage of the technology applied. Approaches based on knowledge, as well as the sociotechnical approach to successful organization of one serious business, presumes mutual cooperation, support and coordination between the management and the employees, as well as information about the organization, the technology applied and the markets, all that with a view to accomplishing the preset business targets.

\section{ORGANIZATIONAL BUSINESS DIMENSION}

Information system management is an organized set of people, procedures, databases and hardware packages providing routine reports on the management. The information system management is a computer-based system providing information and support for the effects of the management's decision making (Daft, 1997, p. 688).

Realization of an organization linked in this way can be done by means of integrated information systems, which requires appropriate skills and knowledge necessary for problems and human resources management, both on an individual and an organization level. That presumes distinguishing between data, information and knowledge. Effective work strategy is dependent on application of information technologies. Latest developments in the field of information technologies initiate: electronic data exchange, electronic payment in all the purchase-sale transactions, electronic network linking directly the customers and the suppliers (Keen, 1991).

There are, however, some conditions and prerequisites needed for creation of a successful and integrated business organization, which are as follows: knowledge that can be used for technology management, in particular for information technology management, and management which will be successful in settling the forthcoming problems. This will enable realization of the organizational dimension of each business. Therefore, knowledge related to information technologies and equipment is a must. This primarily covers hardware equipment, then software programs, whose basis are operation systems and devices for storing digital information and data. Nowadays there is more than one option. Those are modern hard discs and accessory mobile memory media which can store a huge amount of digital data.

More generally speaking, technologies supported by information structure must rely on confidence-based relationships among the networked employees of a business organization. Their objective is to reach a better decision making procedure in the organization, and that is achievable by confidential coordination of the staff working on this type of tasks. Additionally, better quality will be achieved by implementation of appropriate control and planning. 
All this requires expertise as regards coordination of the information technologies, working processes in a business organization, the required conduct in the organization and the real settlement of the business problems.

High information technology improves the organizations' competitiveness. By improvement in management - educative support systems and information systems for decision support - are supposed to aid the organization to raise its competitiveness. Namely, modern information systems reduce the hierarchy and increase the efficiency of the organization.

By means of virtual products, information systems can improve the openness of the organization towards its clients. Information systems and technologies allow the companies to adjust their products offers without having to incur extra costs (Davidow, \& Malone, 1992).

That is the basis on which the information concerning operation of the business can be united. Team work has been and will remain the main tool for data sharing and its distribution, and it can be done either in the traditional, conventional manner, or applying the latest developments in the field of information, computers and telecommunications. This creates the necessary grounds for realization of creativity of the respective business organization, as well as processing of the information needed for knowledge-based performance.

The information system is a computer-based system which, by means of hardware, software and human resources, provides the organization, i.e. its management, with information and suitable communication lines, which, according to the functions performed and the people served, can be: information system management, decision making support system, top management support system and expert system (Simić, 2007, p. 244).

Commonly, the information system relates to technologies, people, organizations and business environments. For people to be able to apply the information systems, they have to have excellent background in education and training. Other significant components are: commitment to work, provision of appropriate working conditions accompanied by users' interfaces and tools for creativity support.

The technological component of an information system comprises: hardware equipment, software applications, data storage devices and gadgets and telecommunication equipment. Hardware equipment needed for creation of an information system, whose aim is business support, consists of PCs (either desktop computers, i.e. working terminals, or mobile computers), computer servers, devices for network communication, telecommunication equipment, and special devices for storage of digital information and data. This equipment is in fact computers described as physical gadgets whose design and software 
applications are designed to ensure data feeding. This data can later be processed applying highly sophisticated software-supported applications and programs designed to transform this data that is ultimately stored in the storage devices.

Computers are generally distinguished from each other by the processing speed of the central processor. It is designed to control the other parts of the computer system, some of which being: working memory, which is aimed at short-lasting storage of data, data storage disk for permanent storage of data and programs, the operation system and a variety of documents. Additional supporting facilities are various screens, digital data storage media, the popular mobile computers and telecommunication equipment used to provide access to the available computer networks. By their size and complexity, computers can be classified into: personal computers, micro and mini computers and supercomputers.

Software applications can be divided into two groups: operation systems and software applications for various purposes and support in case of some specific problems. The latter are associated with software programs earmarked for specific tasks. Some of these programs are, for example, for text processing and office operations, publishing software, software needed for all kinds of working, production and designing processes, software for various calculations, software for e-mail servers, databases, software to support document management, and software for long distance learning. Other software for specific purposes is used for management of networking devices, the popular web software applications used for support and design of internet uploading, as well as e-commerce software designed to ensure trading via the internet.

Operation systems are also referred to as system software. It is a set of programs managing the computer resources which are part of the computer configuration, but can also be additional computer equipment, such as printers, for instance, then a variety of so called peripheral pieces of equipment (e.g. those used for laboratory researches), as well as network computer equipment. Furthermore, there is management program support with computer system activities.

From the above mentioned, it is obvious that there are interrelations among hardware computer equipment, operation software systems, earmarked application programs and the staff working in the business organizations. This is easy to explain by the fact that software packages are designed to ensure integration among people, computer hardware and working processes related to the vision of the respective organization.

Chief purpose of the organization component in any business organization is finding a way to overcome the problem encountered. Due to occurrence of rather complex problems faced by a business organization, and its need to stay BUSINESS SCHOOL, 1/2015, $34-46$ 
competitive on the market, a comprehensive approach is necessary. It should involve application of organization culture, organization management, business policies and business knowledge databases.

Secondly, attention must be paid to complexity of competition and the level of demand, in order to meet these conditions. The need for organization culture arises from the changes occurring in the surroundings of the organization. That is why the changes to happen should imply change in the current structure values.

Management is necessary when there is a drop in the level of control in the organization. The background of such a situation is a number of events that destabilize the business. A commonly applied response is design of a strategic plan to overcome the problems identified and encountered, which refer to sustainability of the business and improvement in production, supposedly resulting into predetermined and expected profitability of the business organization.

Quite often relationships with politics and the society do affect the business. This primarily means being supported when awarded some projects that bear great political significance, because they provide new jobs. This can improve business performance. If the abovementioned projects are additionally supported by knowledge databases that could offer solution guidelines, then it is feasible to achieve the targets preset. Knowledge databases are preferably used when restructuring the business organization, and for application of knowledge concerning the working processes, which is needed to overcome the problem. Lastly, it must be pointed out that the organizational prospects of a business encompass formal rules and procedures, management, organizational culture, production processes, as well as the policies of the business organization.

\section{THE WORLD OF A SUCCESSFULLY INTEGRATED BUSINESS ORGANIZATION}

The main question each manager wonders is what sort of problems can be encountered by his organization, and how to overcome them. Generally, these problems arise from insufficient exploitation of human knowledge and its nonapplication in business operations. Reasons can also be found in poor or insufficiently developed communication within the organization. Overpowering problems with such background must be based on designing concrete alternatives.

These problems require making effective decisions that shall be based on processes resulting into finding a solution for the problem. This process presumes identification of the problem and its clear defining. Only based on 
such information provided can the problem be thoroughly studied and analyzed. However, sometimes this information is insufficient, i.e. additional data is needed to study the problem (Galbraith, 1995). This particularly applies to its dynamics, which should be used as basis for better understating of the problem and finding the best way(s) out of it. Accordingly, the best possible solutions should be designed, and preferably to choose one of them. The stage to follow would imply successful implementation of the solution, and in future check-up of the reliability of the solution in actual market conditions.

Designing successful business solutions implies work on development of logical business design, which later needs to be realized through actual, concrete physical design. Logical design anticipates creation and documentation of a business system that clearly describes what is to be done. Physical design, on the other hand, means concrete, actual specifications regarding the needed information computer equipment. It is mainly hardware equipment, software packages and guidelines how to use them. The leading manufacturers of this type of products present nowadays on the international markets offer quite good support for planning, realization and implementation of these products.

These physical business solutions can be tailored according to the needs of the business itself. They are easily adjustable to the market operation conditions. They can be designed or realized based on computer-telecommunication networks. These business computer networks are usually referred to with various names, depending on their size and distribution of their operation. Accordingly, there are local computer networks, as well as enormous networks covering vast areas.

The purpose of local computer networks is computer networking by means of networking devices, but on smaller areas. Normally they are used in one structure, or in structures located nearby each other. They allow networking of the PCs and the accessory digital equipment. The networking can be by wire or wireless, thus fully realizing the local computer network. Another distinction is whether the networking is accomplished by series or by ring-like configuration.

Physical designing of the local networks configurations necessitates networking devices for computer servers which must be simultaneously networked with its own provider, thus enabling networking with other, related computer networks located far away from each other. Since it is possible to share the computer resources, data storages and software applications, as well as printers and any other accessory equipment, they are highly suitable for business support.

For communication, there is a wide range of applicative software packages, such as the e-mail communication between the business and its business associates and/or clients. These services can be externally provided as well. They enable video teleconferencing, support or share of knowledge within the BUSINESS SCHOOL, 1/2015, $34-46$ 
organization, using, for instance, the mobile computers and their support. It is worthwhile mentioning though, that the organization can also make use of the conventional means of communication.

Local computer networks can be administered by networked management software, as well as with software that allows management of computer communication, in cases when the network configuration is more sophisticated.

Second type of designing computer networks includes networks covering vast areas. Their size is impressive, as they provide networking among continents. Telecommunication connections needed to implement this type of networking can be provided from the local telecommunication providers available at the global market for such services. Consequently, those requesting such services only need to have their own networking equipment, including all the accessories necessary for managing that type of computer networks.

More complex networks can be designed on demand of a specific organization, although a relatively easy way to access the internet is to have your own network or to hire a web server that is supposed to be accessible on the internet. This makes easier the process of advertising and marketing your products/services. In order to achieve that, it is necessary to have a computer network structure supported by appropriate software and hardware equipment. Such are, for example, the well-known server designs of "e-mail" and "web" support. Document management systems are also used, and they are designed for more sophisticated filing of documents, including management of accessibility of all the documents. These systems can also provide protection of the documents, allowing access to authorized users only.

Systems for management of long-distance learning are also important, since they make possible sharing digital data via computer-based available networks. They are very useful for long-distance learning, which can be performed on the internet, too. Regarding the needs for networked digital flow of information, appropriate programs supporting it can be used, although classical way of operation is most commonly applied and still preferred. We must not forget the tools and servers used for designing and operation of web sites, as well as a variety of programs for telecommunications. All of these networks can be designed to operate by wires, fiber optic cables or satellites.

\section{MANAGEMENT AND SOPHISTICATED APPROACH TO WORK ENABLED BY COMPUTER NETWORKS}

In order to enable successful management of the above mentioned informationcomputer systems, which are an integral part of every business organization and are used to support their work processes, special attention must be paid to the 
employees' management. Afterwards, business vision must be defined, and it must be grounded on clear business plans and getting control of the finances. All the management functions designed for the previously mentioned activities can successfully be supported and realized by means of appropriate information software tools earmarked for these purposes.

Apart from the above, management operations are closely connected with successful making use of skills and know-how of individuals able to perform certain concrete work. That is why it is important for the management to duly provide the employees with all the tools needed for doing the work, which will ultimately lead to reaching the targets set. With a view to doing that, the management is supposed to select specific indicators that will allow the management to monitor development processes which lead the business to accomplishment of these predefined goals.

Hence the conclusion that managers are expected to think up the best way how to perform the work containing clearly defined goals. This will necessitate coordination among the employees. Put in other words, the management goals can also be achieved by activities which, for instance, refer to the business goals, and by entrusting certain employees with definite tasks and activities which will lead to realization of the program tasks.

Additionally, the manager can apply some motivating approaches by giving the employees proper guidelines for good performance and successful realization of the tasks. And definitely, the management should monitor all the future activities. In case of deviations or errors in the activities, the employees should be instructed what measures to take and if needed to redesign the activities.

Another task the management is entrusted with is monitoring the relations amongst its employees, all that with the purpose of achieving its goals. The management of this type of sophisticated business systems is supposed to gather information, which will necessitate development of relations with the organization's environment. Sometimes, due to appearance of competitive products on the market, the management is expected to change the priorities and to be actively involved in overcoming the problems, all that with a view to meeting the needs of the business environment.

That is the reason why it is crucially important to monitor the business achievements in the organization itself as well as in the business environment. This can be ensured by the database and knowledgebase, both needed for improvements in performance, which will lead to realization of the future goals (Stewart, \& Ruckdeschel, 1998). They can help in successful settlement of some frequently reoccurring problems. 
Sometimes, yet, the problems are insufficiently studied, thus necessitating additional data and knowledge, all that with the purpose of enabling performance of the analyses needed and finding a suitable solution. This means existence of an appropriate database that will help to properly analyze the problem, using analytic tools. This should lead to adjustment of the business to the needs of its environment, which can also be accomplished by a good-quality production process.

For communication, managers need "e-mail" server services which can be designed either as part of the local computer network, or can be designed as external services, the choice depending on the extent of protection desired. Other communication means are document management software packages and the accessible databases. They can be used for future planning that is to be performed by the employees, based on knowledge and a successful management.

\section{KNOWLEDGE MANAGEMENT USED TO ENHANCE THE ORGANIZATION'S PERFORMANCE}

The developments made in the past decades in the field of informatics, computers and communication equipment made it possible to carry out much more sophisticated analyses and activities requiring high-level expertise (McInerney, 2002). They are applied by people who have constantly been upgrading and perfecting their knowledge, thus making them able to achieve much better results in their researches. Some of their activities include design of information and data that shall further be assessed.

Based on the data provided by the State Statistical Office of the Republic of Macedonia, in the course of the past less than twenty years (1991 - 2013), the number of graduated university students has risen by about $276 \%$. The number of specialized professionals has increased by $970.9 \%$, and in the course of the past three years their average number is 191.33. Quite interesting is the datum regarding the number of postgraduates with MA or MSc degree, whose number in the previous decade, compared to the figure given for the last decade of the previous century, has gone up by $290,5 \%$, ending up with 1508,66 Masters per year for the past few years. The number of $\mathrm{PhDs}$ has also mildly risen in the first decade compared to the $1990 \mathrm{~s}$, the rise being by $164.45 \%$, and the average number of new PhDs for the last few years amounts 187.33 per year. This is due to increment in the number of universities in the Republic of Macedonia, the changes introduced in the curricula and increase in the students' wish to continue their education after graduation.

These social achievements have been accompanied by increment in Gross Domestic Product (GDP), heavier indebtedness of the country, and, what is 
good news, higher export. Hence the need of highly educated and well prepared individuals that will be able to meet the economy's demands, and whose competence will be based on knowledge (Manev, 2003) and the capacity to process data. They all need to be turned into professionals and masters in their fields of operation, supported by the management and the technical employees.

They have to be fully committed to their work, to learning and to creation of knowledge that can successfully be applied in development of competitive products or services. Such work is usually supported by computer networks. On the other hand, for their design we need employees skillful in data processing and management of the computer networks services and of knowledge.

Those are employees who, based on the already gained knowledge, can create the necessary business-related knowledge, can analyze, synthesize and share it, and ultimately use it. Knowledge-based employees are typically with higher education, some of them even having reached scientific achievements. They are masters of proper application of the knowledge bases and databases.

The modern, state-of-the-art products offered by the telecommunication operators, such as smart phones, tablets, mobile computers and access to the internet, as well as the wide range of software applications, make possible and facilitate knowledge-based work. This, in turn, positively affects the productivity of the employees and of the society on a larger scale. In order to ease the organization integration, it is of utmost importance to evenly and uniformly make use of these professionals and their capacities, including the system engineers working in the field of computer networks. In doing so, attention must be paid to connecting the business with its environment, i.e. with its clients, providers and organizations.

This type of work requires interactive and interpersonal cooperation among the employees involved in this type of integration. It is a rather complex activity. Quite often these people are strong individuals who find it easy to cooperate both with their workmates and with the management, are highly skilled and well trained in their field of operation.

Successful operation of a business organization necessitates a computer centre that will ensure integration and linkage of the organization functions. Secondly, the organization needs to be linked with its environment, i.e. its clients, providers, shareholders, government services and internet providers. There are also specialized software tools that support the major functions of the organization, such as management of human resources, finances, marketing of the organization, as well as sales activities.

Apart from the previously mentioned functional organization software packages, support for knowledge-based employees must be carried out by BUSINESS SCHOOL, 1/2015, 34 - 46 
target-focused coordination of people and work, and by project support of the organization activities. Therefore it is necessary to acquire knowledge in fields such as project management and data management, and to provide studies of knowledge bases.

\section{FINAL OBSERVATIONS}

Technological development nowadays requires organizations capable of competing on markets full of top-quality products and services. These are elaborate business organizations whose priorities are efficiency and profitability, bearing in mind all the time the interests of the social environment, as well. These organization hire staff and develop or apply methods, tools and procedures, all that with the intention of reaching the organization's goals.

Recognition of the complexity of these business organizations is a must if business is to survive. The business environment refers to legal regulations, political values, economic conditions and costs arising in the neighborhood and the global changes, as well as the unstoppable development of scientific and technological achievements. It is this dynamic development and changes going on in an organization that need this type of business organizations based on knowledge management.

\section{REFERENCES}

Daft, R.L. (1997). Management. Orlando: The Dryden Press, Harcourt Brace College Publishers.

Davidow, W.H., \& Malone, M.S. (1992). The Virtual Corporation: Structuring and revitalizing the corporation for the 21st century. New York: Harper Business.

Galbraith, J.R. (1995). Designing Organizations: An Executive Briefing on Strategy, Structure and Process. San Francisco: Jossey-Bass Publishers.

Jakimovski, J. (2009). Knowledge and Social Development. In: Collection of Papers, International Conference: Knowledge, Capital of the Future, November 26-27.

Keen, G.W. (1991). Shaping the Future: Business Design Through Information Technology. Harvard Business School Press.

Manev, G. (2003). Strategic Cognitive Management System. Skopje: Institute for Sociological, Political and Legal Research.

McInerney, C. (2002). Knowledge management and the dynamic nature of knowledge. Journal of the American Society for Information Science and Technology, 53(12), 1009-1018. doi:10.1002/asi.10109 
Morton, S. (1992). The Effects of Information Technology on Management and Organizations. In Transforming Organizations. (pp. 261-279).

Porter, M.E. (1988). The Competitive Advantage of Nation. London: Macmillan Press Ltd.

Simić, I. (2007). Menadžment. Niš: Ekonomski fakultet.

Statistical Yearbook of the Republic of Macedonia. Skopje: Statistical Office of the Republic of Macedonia.

Stewart, T., \& Ruckdeschel, C. (1998). Intellectual Capital: The New Wealth of Organizations. Crown Business Publishers.

Received: 30.03 .2015$. Accepted: 02.04.2015. 